\title{
Evaluation of Efficacy of Different Denture Disinfectants on Biofilms Formed on Acrylic Resin
}

\author{
Manumeet Kaur Bhathal ${ }^{1} \quad$ Urvashi Kukreja ${ }^{2} \quad$ Navneet Kukreja ${ }^{3}$ \\ ${ }^{1}$ Department of Prosthodontics, Subharti Dental College, Meerut, \\ Uttar Pradesh, India \\ ${ }^{2}$ Department of Prosthodontics, M.M. College of Dental Science and \\ Research, Mullana, Ambala, Haryana, India \\ ${ }^{3}$ Department of Conservative Dentistry and Endodontics, M.M. \\ College of Dental Science and Research, Mullana, Ambala, Haryana, \\ India
}

\begin{abstract}
Address for correspondence Manumeet Kaur Bhathal, MDS, Department of Prosthodontics, Subharti Dental College, Swami Vivekanand Subharti University, Meerut Cantt, Uttar Pradesh 250001, India (e-mail: meetbhathal@gmail.com).
\end{abstract}

Dent J Adv Stud 2018;6:20-27

Abstract

Keywords

- disinfectants

- infection control

- microorganisms

- acrylic resin
Purpose Health professionals, especially in dentistry, are involved at high risk of microbial cross contamination. There are many studies that reported the risk of cross-contamination in prosthetic laboratories. Although much importance has been given to infection control practices, such as the barrier technique, sterilization, and disinfection of the dental office and instruments, less emphasis has been given for the disinfection of dentures. The dentures in mouth are prosthetic medical devices that create an appropriate habitat for both pathogenic and nonpathogenic organisms to nurture. To avoid cross-contamination, denture disinfection is mandatory. This study evaluated the efficacy of four denture disinfectants on four most common organisms found in denture biofilm at two different time intervals.

Materials and Methods Three hundred twenty denture base acrylic resin specimens were fabricated by means of wax patterns with dimensions diameter $15 \mathrm{~mm} \times 4 \mathrm{~mm}$. The contamination of samples was done by the four microorganisms taken in study that were Staphylococcus aureus, Candida albicans, Pseudomonas aeruginosa, and Escherichia coli. The contaminated samples were disinfected by immersion procedure in four disinfectants that were sodium hypochlorite, glutaraldehyde, peracetic acid, and chloroxylenol.

Results Sodium hypochlorite was the best disinfectant resulting in complete elimination of microorganisms in 5 minutes immersion time. Glutaraldehyde and chloroxylenol were also effective against microorganisms. Minimum 10 minutes immersion time was required to completely eliminate the microorganisms. Peracetic acid was least effective of all showing the least reduction in microbial growth. Among the organisms, S. aureus showed the maximum resistance to disinfection, and $C$. albicans was the least resistant.

\section{Introduction}

Invisibility does not mean nonexistence; opportunity makes the presence felt. It is from the vitality of the atmospheric particles that all the mischief arises.
Nowadays there is high consternation regarding the spread of infectious diseases. More awareness is on several ways of cross-contamination external to the dental operatory, facilitated by the dentist and the dental auxiliary personnel. Patients are becoming more sophisticated in their scrutinizing of the dental and medical professional's approach to asepsis.
DOI https://doi.org/ 10.1055/s-0038-1671696. ISSN 2321-1482.
(C)2018 Bhojia Dental College and Hospital affiliated to Himachal Pradesh University
License terms

(ㅇ) (1) $\ominus \circledast$ 
Health professionals, especially in dentistry, are also involved at high risk of microbial cross-contamination. There are many studies that reported the risk of cross-contamination in prosthetic laboratories. ${ }^{1}$ Although much importance has been given to infection control practices, such as the barrier technique, sterilization, and disinfection of the dental office and instruments, less emphasis has been given for the disinfection of dentures. The dentures in mouth are prosthetic medical devices that create an appropriate habitat for both pathogenic and nonpathogenic organisms to nurture. ${ }^{2}$ So, these dental prostheses create a medium for the transfer of organisms from patients to the dental and laboratory personnel. To avoid cross-contamination and improve the denture hygiene, denture disinfection is mandatory. The use of various disinfectants has been reported. The literature differs markedly regarding the concentration and duration of disinfectants used. Henceforth, this study was intended to evaluate the efficacy of four denture disinfectants on four most common organisms found in denture biofilm at two different time intervals.

\section{Materials and Methods}

\section{Specimen Fabrication}

Three hundred twenty denture base acrylic resin specimens were fabricated by means of wax patterns with the dimensions (diameter $15 \mathrm{~mm}$, width $4 \mathrm{~mm}$ ). The wax samples were prepared in the custom-made metal mold. The wax discs were then invested in dental flasks with type III gypsum product, i.e., dental stone, and dewaxing was done. The heat cure acrylic resin was prepared with polymer:monomer ratio of 3:1 by volume in a mixing jar by using the measuring cylinder. The stone mold was packed in dough stage. Polymerization of acrylic resin was done following a short curing cycle $\left(74^{\circ} \mathrm{C}\right.$ for $2 \mathrm{~h}$ followed by terminal boiling for 1 hour) in acrylizer. After curing, overnight bench cooling was done. The cured samples were deflasked carefully, and finishing was done.

All the samples were sterilized by microwave sterilization. Microwave oven irradiation for sterilization of non-autoclavable dental instruments and dentures was first introduced by Rohrer and Bular. Microwave radiations have thermal effect and non-thermal effect. The thermal effect is due to changes on cell structure, alteration of cell membrane permeability, and cell death. The heat generated by microwaves upon the organic matter is assumed to be the causative factor for these modifications. The non-thermal effect relates to the destruction of microorganisms at temperatures lower than the thermal destruction point. The probable justification lies on the selectivity of microwave irradiation absorbance by certain biochemical molecules, such as protein, nucleic acid, and the protein-lipopolysaccharide compounds of cell membranes, for example, the interaction between electromagnetic field produced by the microwaves, and the cell molecules would lead to cell destruction.

Samples were placed in microwave safe container containing sterile water. Sterilization was done for 3 minutes at $650 \mathrm{~W}$.

\section{Contamination of the Specimens}

The contamination of samples was done by the four microorganisms taken in study. Sixty samples from each group (15 from each subgroup) were contaminated. First, each microbial strain was cultured in a culture medium: Tryptic Soy Broth. Then, each acrylic resin specimen was transferred to containers containing culture medium broth $(200.0 \mathrm{~mL})$ with $1.0 \%$ microbial inoculum at $0.5 \mathrm{McF}$ arland scale. These containers were employed for the formation of biofilm of microorganisms onto the sample's surfaces. The containers with the samples and inoculums had been placed in the incubator for 48 hours at $37^{\circ} \mathrm{C}$. After incubation, there was growth of the particular organism over the samples. The contaminated samples were removed from the broth, gently washed in water, and were employed for disinfection.

\section{Disinfecting the Samples}

Samples from the broth were disinfected by immersion procedure using different disinfectants (sodium hypochlorite, glutaraldehyde, peracetic acid, and chloroxylenol). Ten samples from each subgroup were immersed in disinfectant. Five samples were immersed for 5 minutes and five samples for 10 minutes. The five samples in each subgroup, which were contaminated, were not dipped in disinfectant (positive control). After removing from disinfectant, again all the samples were washed and cultured for colony formation.

\section{Microbial Counting}

The samples were placed in contact with appropriate culture medium contained in a Petri plate. Samples were discarded, and the Petri plates were incubated at $37^{\circ} \mathrm{C}$ for 48 hours. After incubation, the colony-forming unit (CFU) for each

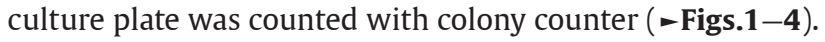
The results obtained were compared to evaluate the efficacy of different denture disinfectants at two time intervals.

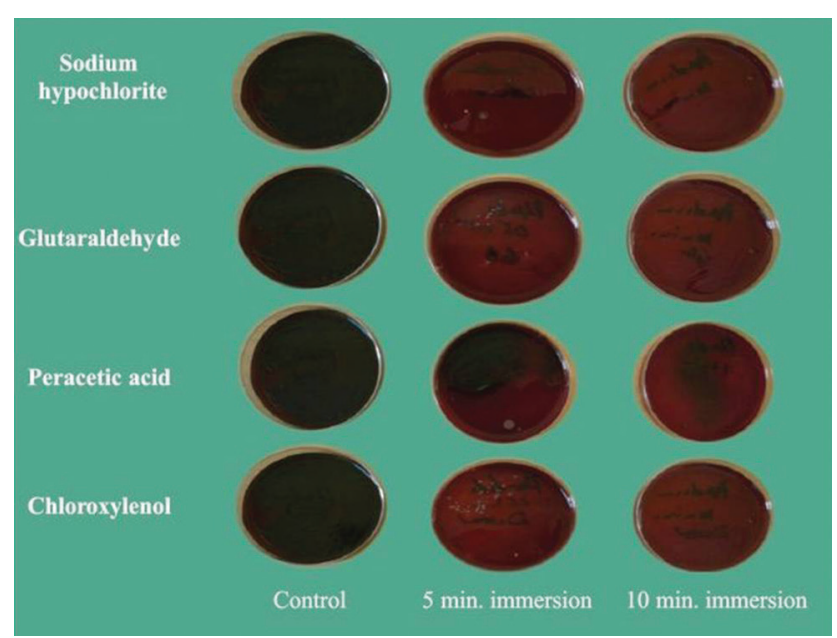

Fig. 1 Blood agar plates showing CFU for Pseudomonas aeruginosa after 5 and 10 minutes immersion. CFU, colony-forming unit. 


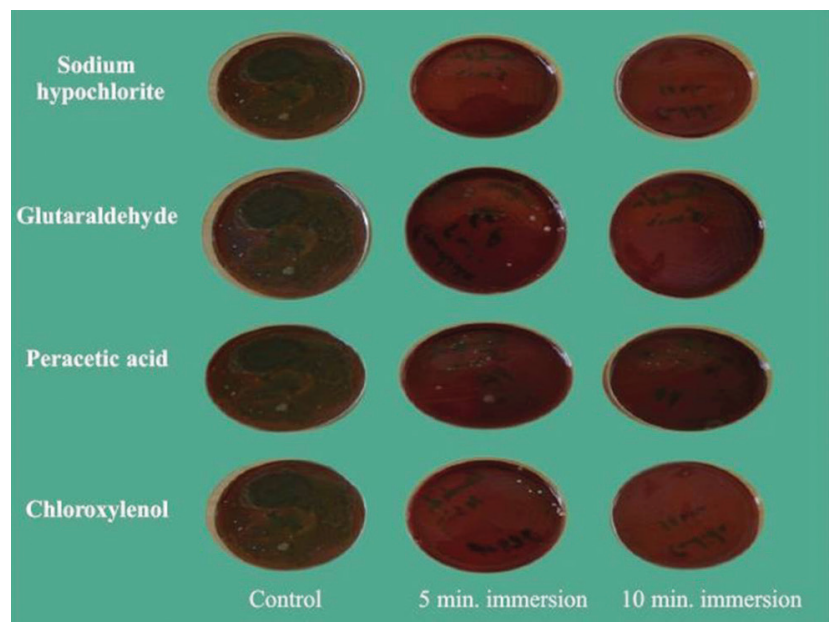

Fig. 2 Blood agar plates showing CFU for Candida albicans after 5 and 10 minutes immersion. CFU, colony-forming unit.

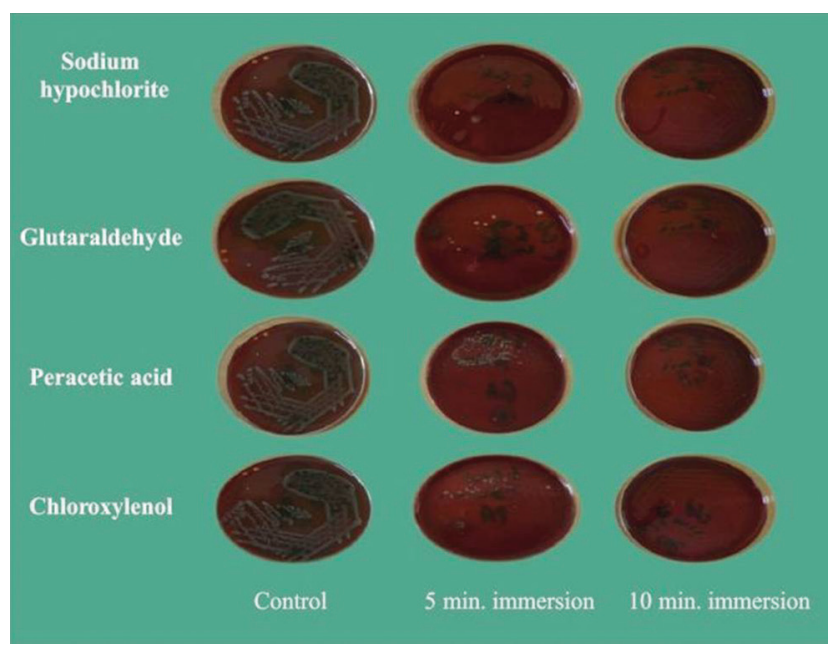

Fig. 3 Blood agar plates showing CFU for E. coli after 5 and 10 minutes immersion. CFU, colony-forming unit.

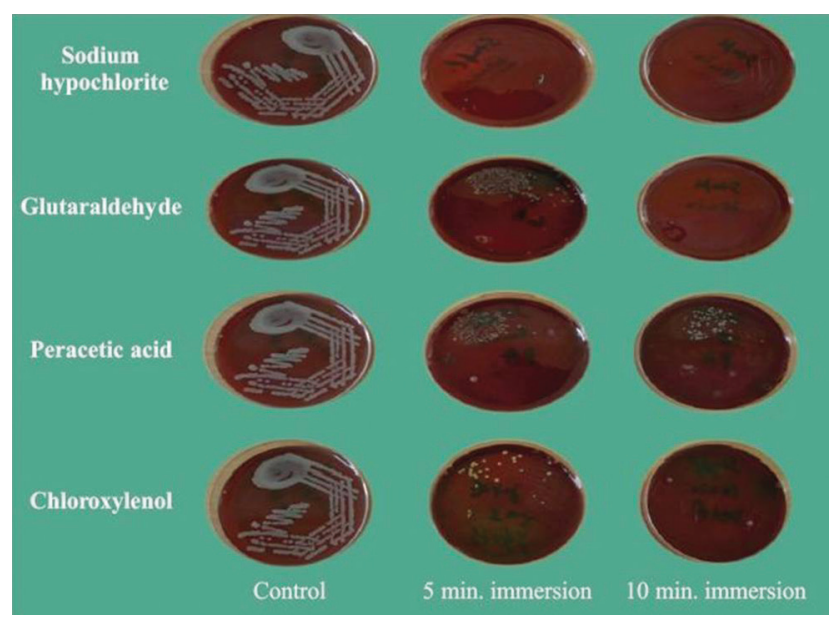

Fig. 4 Blood agar plates showing CFU for Staphylococcus aureus after 5 and 10 minutes immersion. CFU, colony-forming unit.

\section{Results}

The results showing the efficacy of various disinfectants are shown in (-Tables $\mathbf{1 - 4}$ ). There is statistically significant difference among the final counts of microbes after the disinfection. Among the four disinfectants used in the study, sodium hypochlorite was the best disinfectant resulting in complete elimination of microorganisms in 5 minutes immersion time. Glutaraldehyde and chloroxylenol were also effective against microorganisms, but the complete disinfection could not be achieved in 5 minutes immersion. Minimum 10 minutes immersion time was required for glutaraldehyde and chloroxylenol to completely eliminate the microorganisms. Peracetic acid was the least effective of all showing the least reduction in microbial growth. Out of organisms Staphylococcus aureus showed the maximum resistance to disinfection, and Candida albicans was the least resistant.

\section{Discussion}

The human mouth is a repository for many pathogenic microorganisms that are the causative factors of various oral and systemic infections. These oral infections contribute in the pathological process of various systemic diseases, which affects the general prognosis of not only frail, elderly, and immunocompromised patients, but also of those who are healthy. ${ }^{3}$ In recent times, there is a consequent rise in the ratio of elderly within each population. This increase has led to increase in the proportion of population which are immunocompromised and/or have physical health problems such as stroke, aspiration pneumonia, cardiovascular disease, and diabetes. Amid these, aspiration pneumonia grounds for the maximum loss of life in the elderly. The pathogens of aspiration pneumonia, including C. albicans and S. aureus, show high potential to cause pneumonia in the elderly than in young adults. ${ }^{4}$ It has been documented that $C$. albicans strains have the capability to produce carcinogenic nitrosamines from saliva and foster neoplastic changes. The co-existence of Pseudomonas spp. and C. albicans in old population is a potential indicator of a high risk for pneumonia and heart disease. ${ }^{3}$ Escherichia coli is correlated to fecal contamination.

In dental laboratories, the prime source of cross-contamination is the prosthesis, especially the dentures of immune-compromised patients. During the routine laboratory procedures, such as polishing and trimming, the aerosols so produced contain the microorganisms adhered to these dentures which are capable of infecting the professional and objects used daily, such as polishing brushes, burs, lathe, and pumice stone. ${ }^{4,5}$

In view of this, compliance with the universal biosecurity policies, such as the adoption of strict disinfection measures, is of paramount importance to prevent interpatient microbiological cross-contamination within the dental office and laboratory. ${ }^{6}$ Recommendations exist for the use of safety measures as well as for disinfection techniques. To address these cross-contamination concerns, the American Dental 
Table 1 Results obtained for the antimicrobial effectiveness of sodium hypochlorite after 5 and 10 minutes immersion

\begin{tabular}{|c|c|c|c|c|c|c|}
\hline Group & & & $N$ & Mean & Standard deviation & Standard error \\
\hline \multirow[t]{20}{*}{$\begin{array}{l}\text { Sodium } \\
\text { hypochlorite }\end{array}$} & \multirow[t]{5}{*}{ Staphylococcus aureus } & $\begin{array}{l}\text { Positive } \\
\text { control }\end{array}$ & 5 & 213.8000 & 6.97854 & 3.12090 \\
\hline & & $\begin{array}{l}\text { 5-minute } \\
\text { dipping }\end{array}$ & 5 & 1.2000 & 1.78885 & 0.80000 \\
\hline & & $\begin{array}{l}\text { 10-minute } \\
\text { dipping }\end{array}$ & 5 & 0.2000 & 0.44721 & 0.20000 \\
\hline & & $\begin{array}{l}\text { Negative } \\
\text { control }\end{array}$ & 5 & 00 & 00 & 00 \\
\hline & & Total & 20 & 53.8000 & 94.83481 & 21.20571 \\
\hline & \multirow[t]{5}{*}{ Escherichia coli } & Control & 5 & 227.2000 & 7.08520 & 3.16860 \\
\hline & & $\begin{array}{l}\text { 5-minute } \\
\text { dipping }\end{array}$ & 5 & 0.4000 & 0.54772 & 0.24495 \\
\hline & & $\begin{array}{l}\text { 10-minute } \\
\text { dipping }\end{array}$ & 5 & 0.0000 & 0.00000 & 0.00000 \\
\hline & & $\begin{array}{l}\text { Negative } \\
\text { control }\end{array}$ & 5 & 00 & 00 & 00 \\
\hline & & Total & 20 & 56.9000 & 100.92983 & 22.56860 \\
\hline & \multirow[t]{5}{*}{ Candida albicans } & Control & 5 & 243.0000 & 13.37909 & 5.98331 \\
\hline & & $\begin{array}{l}\text { 5-minute } \\
\text { dipping }\end{array}$ & 5 & 0.0000 & 0.00000 & 0.00000 \\
\hline & & $\begin{array}{l}\text { 10-minute } \\
\text { dipping }\end{array}$ & 5 & 0.0000 & 0.00000 & 0.00000 \\
\hline & & $\begin{array}{l}\text { Negative } \\
\text { control }\end{array}$ & 5 & 00 & 00 & 00 \\
\hline & & Total & 20 & 60.7500 & 108.12998 & 24.17860 \\
\hline & \multirow{5}{*}{$\begin{array}{l}\text { Pseudomonas } \\
\text { aeruginosa }\end{array}$} & Control & 5 & 256.8000 & 5.35724 & 2.39583 \\
\hline & & $\begin{array}{l}\text { 5-minute } \\
\text { dipping }\end{array}$ & 5 & 0.0000 & 0.00000 & 0.00000 \\
\hline & & $\begin{array}{l}\text { 10-minute } \\
\text { dipping }\end{array}$ & 5 & 0.0000 & 0.00000 & 0.00000 \\
\hline & & $\begin{array}{l}\text { Negative } \\
\text { control }\end{array}$ & 5 & 00 & 00 & 00 \\
\hline & & Total & 20 & 64.2000 & 114.11287 & 25.51641 \\
\hline
\end{tabular}

Association issued guidelines for disinfection in 1985, 1988, and $1996 .^{7-9}$ Similar guidelines were given by the British Dental Association, Centre for Disease Control, Occupational Safety and Health Administration, and Environment Protective Agency. They all recommend use of disinfection for prevention of cross-contamination.

Disinfection of dentures should be done at a standard time interval to keep the dentures free from microorganisms. For disinfection, alternative methods have been proposed such as chemical disinfection, ${ }^{10}$ microwave, ${ }^{11}$ and ultraviolet radiation. ${ }^{12}$ However, chemical disinfection, preferably by immersion, seems to be the most reliable and practical method. ${ }^{13}$ Literature differs markedly in the concentration, type, and immersion times of disinfection protocols, making it difficult to assess the most appropriate method. Commonly used chemical disinfectants are alcohols, aldehydes, chlorine compounds, phenolics biguanides, iodine compounds, and quaternary ammonium compounds. ${ }^{14}$
Sodium hypochlorite and glutaraldehyde have been widely recommended for disinfection. ${ }^{15}$ Peracetic acid was introduced in market in 1998 and has been indicated for high-level disinfection and sterilization of critical and semi-critical articles. ${ }^{16}$ Chloroxylenol is being routinely used in household disinfection, but no study has been done on its use as denture disinfectant.

Therefore, the present study was conducted to evaluate the efficacy of above-mentioned four denture disinfectants on biofilms formed on acrylic resins at two different time intervals, i.e., 5 minutes and 10 minutes. A total 320 acrylic samples were prepared and were contaminated by four organisms Staphylococcus aureus, E. coli, C. albicans, and $P$. aeruginosa. Disinfection was done by immersion method for 5 minutes and 10 minutes in each disinfectant.

When the samples contaminated with all the four organisms were dipped in sodium hypochlorite, the results showed that sodium hypochlorite was highly effective against all the organisms. The results are in concurrence with the study 
Table 2 Results obtained for the antimicrobial effectiveness of glutaraldehyde after 5 and 10 minutes immersion

\begin{tabular}{|c|c|c|c|c|c|c|}
\hline \multirow[t]{20}{*}{ Glutaraldehyde } & \multirow[t]{5}{*}{ Staphylococcus aureus } & Control & 5 & 213.4000 & 5.77062 & 2.58070 \\
\hline & & $\begin{array}{l}\text { 5-minute } \\
\text { dipping }\end{array}$ & 5 & 28.0000 & 14.67992 & 6.56506 \\
\hline & & $\begin{array}{l}\text { 10-minute } \\
\text { dipping }\end{array}$ & 5 & 0.8000 & 1.09545 & 0.48990 \\
\hline & & $\begin{array}{l}\text { Negative } \\
\text { control }\end{array}$ & 5 & 00 & 00 & 00 \\
\hline & & Total & 20 & 60.5500 & 91.56388 & 20.47431 \\
\hline & \multirow[t]{5}{*}{ Escherichia coli } & Control & 5 & 222.0000 & 9.19239 & 4.11096 \\
\hline & & $\begin{array}{l}\text { 5-minute } \\
\text { dipping }\end{array}$ & 5 & 18.8000 & 6.37966 & 2.85307 \\
\hline & & $\begin{array}{l}\text { 10-minute } \\
\text { dipping }\end{array}$ & 5 & 0.2000 & 0.44721 & 0.20000 \\
\hline & & $\begin{array}{l}\text { Negative } \\
\text { control }\end{array}$ & 5 & 00 & 00 & 00 \\
\hline & & Total & 20 & 60.2500 & 96.26929 & 21.52647 \\
\hline & \multirow[t]{5}{*}{ Candida albicans } & Control & 5 & 244.2000 & 5.31037 & 2.37487 \\
\hline & & $\begin{array}{l}\text { 5-minute } \\
\text { dipping }\end{array}$ & 5 & 16.8000 & 6.79706 & 3.03974 \\
\hline & & $\begin{array}{l}\text { 10-minute } \\
\text { dipping }\end{array}$ & 5 & 0.2000 & 0.44721 & 0.20000 \\
\hline & & $\begin{array}{l}\text { Negative } \\
\text { control }\end{array}$ & 5 & 00 & 00 & 00 \\
\hline & & Total & 20 & 65.3000 & 106.27576 & 23.76398 \\
\hline & \multirow[t]{5}{*}{ Pseudomonas aeruginosa } & Control & 5 & 257.2000 & 10.08464 & 4.50999 \\
\hline & & $\begin{array}{l}\text { 5-minute } \\
\text { dipping }\end{array}$ & 5 & 6.4000 & 3.64692 & 1.63095 \\
\hline & & $\begin{array}{l}\text { 10-minute } \\
\text { dipping }\end{array}$ & 5 & 0.2000 & 0.44721 & 0.20000 \\
\hline & & $\begin{array}{l}\text { Negative } \\
\text { control }\end{array}$ & 5 & 00 & 00 & 00 \\
\hline & & Total & 20 & 65.9500 & 113.42444 & 25.36247 \\
\hline
\end{tabular}

done by Bell et al $^{17}$ who compared the biocidal effectiveness of $5.25 \%$ sodium hypochlorite (1:10 dilution) on acrylic strips inoculated with microorganism S. aureus, E. coli, and C. albicans. The result showed that sodium hypochlorite achieved complete disinfection of all the three microorganisms in 4 minutes. No significant difference was found in 5 minutes immersion and 10 minutes immersion for all the organisms suggesting that 5 minutes immersion in sodium hypochlorite is sufficient to achieve disinfection. This is in agreement with Rudd et $\mathrm{al}^{18}$ who studied the antimicrobial action of sodium hypochlorite for the sterilization of complete dentures and determined the time for which the prosthesis should be immersed to achieve this effect. The dentures were coated with the S. aureus, Bacillus subtilis (both vegetative and spore forms), C. albicans, $P$. aerugino$s a$, and Streptococcus (enterococcus) and then immersed in sodium hypochlorite for 1 and 3 minutes showed evidence of growth, whereas the dentures immersed for 5 minutes were sterile.

The results of immersion in glutaraldehyde showed that glutaraldehyde was effective in decreasing the microbial load after 5 minutes, but 10 minutes immersion is required to achieve complete disinfection. The results are in accordance with the study done by Henderson et $\mathrm{al}^{19}$ who evaluated the disinfection of prosthesis with full strength Sporicidin (2\% glutaraldehyde), 1:6 Sporicidin solutions, and 5.25\% sodium hypochlorite (undiluted Clorox) and confirmed that after 10 minutes full strength, Sporicidin was effective in reducing or eliminating culturable aerobic bacteria. Bal et $\mathrm{al}^{20}$ also concluded that 10 minutes immersion in $2 \%$ glutaraldehyde and $0.525 \%$ sodium was effective for disinfection and great reduction of microorganisms.

The results of peracetic acid immersion depicted that though the number of colonies were reduced, but complete disinfection was not achieved even after 10 minutes disinfection. The results are supported by the study of Stopiglia et $\mathrm{al}^{21}$ who concluded in their study that after 5 minutes disinfection with $0.2 \%$, peracetic acid was effective against C. albicans, but was ineffective against E. coli, S. aureus, and P. aeruginosa. ${ }^{22}$ Ceretta et $\mathrm{al}^{23}$ evaluated the effectiveness of peracetic acid in the sterilization of dental equipment and concluded that immersion of the materials in peracetic acid 
Table 3 Results obtained for the antimicrobial effectiveness of chloroxylenol after 5 and 10 minutes immersion

\begin{tabular}{|c|c|c|c|c|c|c|}
\hline \multirow[t]{20}{*}{ Chloroxylenol } & \multirow[t]{5}{*}{ Staphylococcus aureus } & Control & 5 & 216.2000 & 4.71169 & 2.10713 \\
\hline & & $\begin{array}{l}\text { 5-minute } \\
\text { dipping }\end{array}$ & 5 & 31.2000 & 5.58570 & 2.49800 \\
\hline & & $\begin{array}{l}\text { 10-minute } \\
\text { dipping }\end{array}$ & 5 & 3.6000 & 1.67332 & 0.74833 \\
\hline & & $\begin{array}{l}\text { Negative } \\
\text { control }\end{array}$ & 5 & 00 & 00 & 00 \\
\hline & & Total & 20 & 62.7500 & 91.80005 & 20.52712 \\
\hline & \multirow[t]{5}{*}{ Escherichia coli } & Control & 5 & 226.6000 & 11.54556 & 5.16333 \\
\hline & & $\begin{array}{l}\text { 5-minute } \\
\text { dipping }\end{array}$ & 5 & 8.6000 & 1.94936 & 0.87178 \\
\hline & & $\begin{array}{l}\text { 10-minute } \\
\text { dipping }\end{array}$ & 5 & 0.0000 & 0.00000 & 0.00000 \\
\hline & & $\begin{array}{l}\text { Negative } \\
\text { control }\end{array}$ & 5 & 00 & 00 & 00 \\
\hline & & Total & 20 & 58.8000 & 99.60638 & 22.27266 \\
\hline & \multirow[t]{5}{*}{ Candida albicans } & Control & 5 & 250.4000 & 6.87750 & 3.07571 \\
\hline & & $\begin{array}{l}\text { 5-minute } \\
\text { dipping }\end{array}$ & 5 & 6.8000 & 3.70135 & 1.65529 \\
\hline & & $\begin{array}{l}\text { 10-minute } \\
\text { dipping }\end{array}$ & 5 & 0.0000 & 0.00000 & 0.00000 \\
\hline & & $\begin{array}{l}\text { Negative } \\
\text { control }\end{array}$ & 5 & 00 & 00 & 00 \\
\hline & & Total & 20 & 64.3000 & 110.33113 & 24.67079 \\
\hline & \multirow[t]{5}{*}{ Pseudomonas aeruginosa } & Control & 5 & 263.6000 & 12.17785 & 5.44610 \\
\hline & & $\begin{array}{l}\text { 5-minute } \\
\text { dipping }\end{array}$ & 5 & 22.4000 & 8.59069 & 3.84187 \\
\hline & & $\begin{array}{l}\text { 10-minute } \\
\text { dipping }\end{array}$ & 5 & 0.8000 & 1.09545 & 0.48990 \\
\hline & & $\begin{array}{l}\text { Negative } \\
\text { control }\end{array}$ & 5 & 00 & 00 & 00 \\
\hline & & Total & 20 & 71.7000 & 114.25092 & 25.54728 \\
\hline
\end{tabular}

solution at a concentration of 2,500 ppm for 20 minutes promoted complete sterilization. Sukhija et al concluded in their study that peracetic acid was most effective followed by glutaraldehyde and sodium hypochlorite; the latter disinfectants were comparable in their antimicrobial effect. ${ }^{24}$

The results of immersion in chloroxylenol showed that chloroxylenol achieved disinfection after 10 minutes. Five minutes immersion was inappropriate. The literature reviewed did not show any study involving chloroxylenol as denture disinfectant. Chemically, chloroxylenol is a phenolic compound, and phenols have been recommended as denture disinfectants. ${ }^{25}$

So, from results, it can be inferred that sodium hypochlorite was effective disinfectant for 5 minutes and 10 minutes against all the microorganisms taken in the study. Glutaraldehyde and chloroxylenol achieved complete disinfection after 10 minutes. For peracetic acid, disinfection could not be achieved even after 10 minutes. The results are in agreement with study of da silva $\mathrm{FC}^{26}$ in which they evaluated the efficacy of the effectiveness of various disinfectant solutions in the disinfection of acrylic resin specimens contaminated in vitro by C. albicans, Streptococcus mutans, S. aureus, E. coli, or $B$. subtilis. The results showed that sodium hypochlorite showed the highest antimicrobial activity. Glutaraldehyde and chlorhexidine gluconate showed similar activity. Vinegar, sodium perborate, and sodium perborate-based tabs showed no sporicidal activity. The Council of Dental Therapeutics ${ }^{8}$ has also suggested the use of glutaraldehyde and sodium hypochlorite for 10 minutes for achieving complete disinfection.

Out of organisms, S. aureus was found to be the most resistant to disinfection and $C$. albicans to be the least resistant. It has been documented that some antiseptics and disinfectants are rather less effective to $S$. aureus strains that carry a plasmid carrying genes encoding resistance. ${ }^{27}$ The study of Saha et $\mathrm{al}^{28}$ showed similar results in which the effect of six types of antiseptics and disinfectants, namely Dettol (chloroxylenol), Savlon (chlorhexidine gluconate and cetrimide), iodine, phenyl, formalin, and hydrogen peroxide $\left(\mathrm{H}_{2} \mathrm{O}_{2}\right)$ was studied on $\mathrm{S}$. aureus, Salmonella typhi, Shigella dysenteriae, Klebsiella species, and E. coli. S. aureus showed the maximum resistance to disinfectants tested. E. coli and $P$. aeurginosa showed more resistance than $C$. albicans 
Table 4 Results obtained for the antimicrobial effectiveness of peracetic acid after 5 and 10 minutes immersion

\begin{tabular}{|c|c|c|c|c|c|c|}
\hline \multirow[t]{20}{*}{ Peracetic acid } & \multirow[t]{5}{*}{ Staphylococcus aureus } & Control & 5 & 213.2000 & 6.14003 & 2.74591 \\
\hline & & 5-minute dipping & 5 & 79.6000 & 15.91540 & 7.11758 \\
\hline & & 10-minute dipping & 5 & 42.4000 & 5.22494 & 2.33666 \\
\hline & & Negative control & 5 & 00 & 00 & 00 \\
\hline & & Total & 20 & 83.8000 & 82.32324 & 18.40804 \\
\hline & \multirow[t]{5}{*}{ Escherichia coli } & Control & 5 & 219.0000 & 8.06226 & 3.60555 \\
\hline & & 5-minute dipping & 5 & 25.2000 & 4.86826 & 2.17715 \\
\hline & & 10-minute dipping & 5 & 1.6000 & 2.50998 & 1.12250 \\
\hline & & Negative control & 5 & 00 & 00 & 00 \\
\hline & & Total & 20 & 61.4500 & 93.99075 & 21.01697 \\
\hline & \multirow[t]{5}{*}{ Candida albicans } & Control & 5 & 240.2000 & 8.28855 & 3.70675 \\
\hline & & 5-minute dipping & 5 & 18.2000 & 6.05805 & 2.70924 \\
\hline & & 10-minute dipping & 5 & 5.6000 & 1.14018 & 0.50990 \\
\hline & & Negative control & 5 & 00 & 00 & 00 \\
\hline & & Total & 20 & 66.0000 & 103.51710 & 23.14713 \\
\hline & \multirow{5}{*}{$\begin{array}{l}\text { Pseudomonas } \\
\text { aeruginosa }\end{array}$} & Control & 5 & 256.2000 & 7.22496 & 3.23110 \\
\hline & & 5-minute dipping & 5 & 88.6000 & 8.23408 & 3.68239 \\
\hline & & 10-minute dipping & 5 & 43.4000 & 5.94138 & 2.65707 \\
\hline & & Negative control & 5 & 00 & 00 & 00 \\
\hline & & Total & 20 & 97.0500 & 99.76471 & 22.30807 \\
\hline
\end{tabular}

because generally the Gram-negative bacteria are more resistant to disinfection than yeast or fungi. ${ }^{29}$

The present study recommends that sodium hypochlorite $5.25 \%$ (1:10 dilution), glutaraldehyde $2 \%$, and chloroxylenol $0.48 \%$ for 10 minutes immersion time can be used in the dental clinic, in the laboratory, and for the patient to prevent cross-contamination and to maintain good denture hygiene for the patient.

\section{Conclusion}

To prevent the transmission of disease and for good oral hygiene of the oral cavity, denture disinfection is recommended. Immersion in $5.25 \%$ sodium hypochlorite (1:10 dilution) for 5 minutes and in glutaraldehyde and chloroxylenol for 10 minutes is highly effective in achieving complete disinfection. It has to be the responsibility of each associate of dental health team to make certain that all required measures are taken to fend off any cross-infection to both patients and to themselves.

\section{Conflict of Interest}

None.

\section{References}

1 Li J, Helmerhorst EJ, Leone CW, et al. Identification of early microbial colonizers in human dental biofilm. J Appl Microbiol 2004;97(6):1311-1318

2 Agostinho AM, Miyoshi PR, Gnoatto N, Paranhos HdeF, Figueiredo LC, Salvador SL. Cross-contamination in the dental laboratory through the polishing procedure of complete dentures. Braz Dent J 2004;15(2):138-143
3 Abaci O, Haliki-Uztan A, Ozturk B, Toksavul S, Ulusoy M, Boyacioglu H. Determining Candida spp. incidence in denture wearers. Mycopathologia 2010;169(5):365-372

4 Ryu M, Ueda T, Saito T, Yasui M, Ishihara K, Sakurai K. Oral environmental factors affecting number of microbes in saliva of complete denture wearers. J Oral Rehabil 2010;37(3):194-201

5 Kahn RC, Lancaster MV, Kate W Jr. The microbiologic cross-contamination of dental prostheses. J Prosthet Dent 1982;47(5):556-559

6 Crawford JJ. State-of-the-art: practical infection control in dentistry. J Am Dent Assoc 1985;110(4):629-633

7 Council on Dental Therapeutics. Council on Prosthetic Services and Dental Laboratory Relations. Guidelines for infection control in the dental office and the commercial dental laboratory. J Am Dent Assoc 1985;110(6):969-972

8 Council on Dental Practice. Council on Dental Therapeutics. Infection control recommendations for the dental office and the dental laboratory. Council on Dental Materials, Instruments, and Equipment. J Am Dent Assoc 1988;116(2):241-248

9 ADA Council on Scientific Affairs and ADA Council on Dental Practice. Infection control recommendations for the dental office and the dental laboratory. J Am Dent Assoc 1996;127(5):672-680

10 Mueller HJ, Greener EH. Characterization of some denture cleansers. J Prosthet Dent 1980;43(5):491-496

11 Dixon DL, Breeding LC, Faler TA. Microwave disinfection of denture base materials colonized with Candida albicans. J Prosthet Dent 1999;81(2):207-214

12 Ishida $\mathrm{H}$, Nahara Y, Tamamoto M, Hamada T. The fungicidal effect of ultraviolet light on impression materials. J Prosthet Dent 1991;65(4):532-535

13 Al-Jabrah O, Al-Shumailan Y, Al-Rashdan M. Antimicrobial effect of 4 disinfectants on alginate, polyether, and polyvinyl siloxane impression materials. Int J Prosthodont 2007;20(3):299-307

14 Molinari JA, Runnells RR. Role of disinfectants in infection control. Dent Clin North Am 1991;35(2):323-337 
15 Bloomfield SF, Smith-Burchnell CA, Dalgleish AG. Evaluation of hypochlorite-releasing disinfectants against the human immunodeficiency virus (HIV) J Hosp Infect 1990;15(3):273-278

16 Chassot ALC, Poisl MIP, Samuel SM. In vivo and in vitro evaluation of the efficacy of a peracetic acid-based disinfectant for decontamination of acrylic resins. Braz Dent J 2006;17(2):117-121

17 Bell JA, Brockmann SL, Feil P, Sackuvich DA. The effectiveness of two disinfectants on denture base acrylic resin with an organic load. J Prosthet Dent 1989;61(5):580-583

18 Rudd RW, Senia ES, McCleskey FK, Adams ED Jr. Sterilization of complete dentures with sodium hypochlorite. J Prosthet Dent 1984;51(3):318-321

19 Henderson CW, Schwartz RS, Herbold ET, Mayhew RB. Evaluation of the barrier system, an infection control system for the dental laboratory. J Prosthet Dent 1987;58(4):517-521

20 Turhan Bal B, Yilmaz H, Aydin C, Al FD, Sultan N. Efficacy of various disinfecting agents on the reduction of bacteria from the surface of silicone and polyether impression materials. Eur J Prosthodont Restor Dent 2007;15(4):177-182

21 Stopiglia CDO, Carissimi M, Scroferneker ML, Fortes CBB. Microbiological evaluation of peracetic acid for disinfection of acrylic resins. Rev Odonto Ciênc 2011;26(3):238-241

22 Sukhija U, Kukreja N, Bansal A, Bansa J. Peracetic acid: a powerful Bactericidal weapon: a review. J Updates Dent 2017;8(2):18-21
23 Ceretta R, Paula MM, Angioletto E, et al. Evaluation of the effectiveness of peracetic acid in the sterilization of dental equipment. Indian J Med Microbiol 2008;26(2):117-122

24 Sukhija U, Rathee M, Kukreja N, Khindria S, Singh V, Palaskar J. Efficacy of various disinfectants on dental impression materials. Internet J Dent Sci. 2009;9(1):1-9

25 Look JO, Clay DJ, Gong K, Messer HH. Preliminary results from disinfection of irreversible hydrocolloid impressions. J Prosthet Dent 1990;63(6):701-707

26 da Silva FC, Kimpara ET, Mancini MN, Balducci I, Jorge AOC, Koga-Ito CY. Effectiveness of six different disinfectants on removing five microbial species and effects on the topographic characteristics of acrylic resin. J Prosthodont 2008;17(8):627-633

27 al-Masaudi SB, Day MJ, Russell AD. Antimicrobial resistance and gene transfer in Staphylococcus aureus. J Appl Bacteriol 1991;70(4):279-290

28 Saha AK, Haque MF, Karmaker S, Mohanta MK. Antibacterial effects of some antiseptics and disinfectants. J Life Earth Sci 2009;3(4):19-21

29 McDonnell G, Russell AD. Antiseptics and disinfectants: activity, action, and resistance. Clin Microbiol Rev 1999;12(1):147-179 